\title{
Permafrost Thaw and Liberation of Inorganic Nitrogen in Eastern Siberia
}

\author{
Fabian Beermann, ${ }^{1 *}$ (D) Moritz Langer, ${ }^{2,3}$ (D) Sebastian Wetterich, ${ }^{3}$ Jens Strauss, ${ }^{3}$ (D) Julia Boike, ${ }^{3}$ Claudia Fiencke, ${ }^{1}$ \\ Lutz Schirrmeister, ${ }^{3}$ Eva-Maria Pfeiffer ${ }^{1}$ and Lars Kutzbach ${ }^{1}$ \\ ${ }^{1}$ Center for Earth System Research and Sustainability, Institute of Soil Sciences, Universität Hamburg, Hamburg, Germany \\ 2 Department of Geography, Humboldt-Universität zu Berlin, Berlin, Germany \\ ${ }^{3}$ Department of Periglacial Research, Alfred Wegener Institute, Helmholtz Centre for Polar and Marine Research, Potsdam, Germany
}

\begin{abstract}
The currently observed climate warming will lead to widespread degradation of near-surface permafrost, which may release substantial amounts of inorganic nitrogen $(\mathrm{N})$ into arctic ecosystems. We studied 11 soil profiles at three different sites in arctic eastern Siberia to assess the amount of inorganic $\mathrm{N}$ stored in arctic permafrost soils. We modelled the potential thickening of the active layer for these sites using the CryoGrid 2 permafrost model and representative concentration pathways (RCPs) 4.5 (a stabilisation scenario) and 8.5 (a business as usual emission scenario, with increasing carbon emissions). The modelled increases in active-layer thickness (ALT) were used to estimate potential annual liberation of inorganic $\mathrm{N}$ from permafrost soils during the course of climate change. We observed significant stores of inorganic ammonium in permafrost, up to 40-fold higher than in the active layer. The modelled increase in ALT under the RCP8.5 scenario can result in substantial liberation of N, reaching values up to the order of magnitude of annual fixation of atmospheric $\mathrm{N}$ in arctic soils. However, the thaw-induced liberation of $\mathrm{N}$ represents only a small flux in comparison with the overall ecosystem $\mathrm{N}$ cycling. Copyright (C) 2017 John Wiley \& Sons, Ltd.
\end{abstract}

KEY WORDS: climate change; permafrost thaw; nitrogen; polygonal tundra

\section{INTRODUCTION}

The projected increases in air and ground temperatures in high latitudes will have major impacts on arctic ecosystems. Increased rates of microbial decomposition in response to higher soil temperatures can only lead to increased nutrient availability (MacDonald et al., 1995; Rustad et al., 2001; Keuper et al., 2012; Schaeffer et al., 2013). Increased nutrient availability and long-term warming at high latitudes can compensate for increased greenhouse gas emissions by increased primary production (Natali et al., 2012; Sistla et al., 2013). Furthermore, as nitrogen (N) is known to be a main limiting nutrient for plant growth in the arctic tundra (Shaver et al., 1992; Beermann et al., 2015), increased $\mathrm{N}$ availability will influence primary production (Natali et al., 2012) and the plant community composition of arctic ecosystems (Aerts, 2006; Eriksson et al., 2010; Sistla et al.,

* Correspondence to: F. Beermann, Center for Earth System Research and Sustainability, Institute of Soil Sciences, Universität Hamburg, Allende Platz 2, D-20146 Hamburg, Germany. E-mail: fabian. beermann@gmail.com
2013). Changes in the plant species composition of arctic ecosystems will control different positive climate feedback mechanisms such as a reduction of the surface albedo and amplification of the regional greenhouse warming by increased evapotranspiration (Foley, 2005; Swann et al., 2010; Loranty et al., 2011). On the other hand, shrub expansion may also reduce permafrost thaw by increased shading in summer due to the high leaf area (Blok et al., 2010). Thus, nutrient availability indirectly controls both positive and negative feedback mechanisms to climate warming and is an important factor for the development of arctic ecosystems. Furthermore, there is evidence that increased temperatures and permafrost degradation can also lead to increased denitrification (Repo et al., 2009; Elberling et al., 2010) and increased hydrological export (McClelland et al., 2007; Abbott et al., 2015), both removing $\mathrm{N}$ from these soils.

There have been recent attempts to quantify the total $\mathrm{N}$ stock of arctic permafrost-affected soils (Harden et al., 2012; Zubrzycki et al., 2013). Northern peatland soils alone store $8-15 \mathrm{Pg} \mathrm{N}$, which is approximately 10 per cent of the global soil organic matter N pool (Limpens et al., 2006; 
Loisel et al., 2014). However, only small proportions of this $\mathrm{N}$ are available for plant nutrition as dissolved inorganic nitrogen (DIN) and, moreover, plants can also take up organic $\mathrm{N}$ forms such as amino acids and oligopeptides (Chapin et al., 1993; Schimel and Bennett, 2004). Thus, total N alone is not an appropriate measure to describe the current $\mathrm{N}$ availability in arctic permafrost-affected soils and additional information about dissolved $\mathrm{N}$ compounds is needed.

Despite frequent studies investigating the availability of inorganic $\mathrm{N}$ in the active layer of permafrost-affected soils (e.g. Nadelhoffer et al., 1992; Chapin, 1996; Weintraub and Schimel, 2005a; Rodionov et al., 2007; Chu and Grogan, 2009), few studies have quantified inorganic N compounds in permafrost. Recently, Keuper et al. (2012) found significant amounts of ammonium in permafrost of Swedish peatlands. Furthermore, the release of large amounts of inorganic $\mathrm{N}$ from thawing permafrost of arctic and alpine permafrost environments has been reported (Barnes et al., 2014; Harms et al., 2014), and increased uptake of $\mathrm{N}$ by plants following permafrost thaw was observed (Schuur et al., 2007). Although there is growing evidence of plant-available $\mathrm{N}$ stores in arctic and alpine permafrost-affected soils, uncertainties are high and data from Siberia - the largest tundra region of the world - are sparse.

The present study aims to quantify the potential liberation of inorganic $\mathrm{N}$ (including $\mathrm{NH}_{4}^{+}$and $\mathrm{NO}_{3}^{-}$) from thawing permafrost. Eleven soil profiles up to $1 \mathrm{~m}$ depth below the surface (b.s.) were studied in the Lena River Delta as well as in the lowlands of the Indigirka River and in the Kolyma River Delta (Republic of Sakha, Russian Federation; Figure 1). By modelling the potential active-layer thickness (ALT) increase of the studied soils in the course of climate change, we roughly estimate the potential annual liberation of inorganic $\mathrm{N}$ in these ecosystems in the coming decades. Detailed cryolithological analyses of the studied soil profiles provide reliable input data for the ALT modelling.

\section{MATERIALS AND METHODS}

\section{Site Descriptions}

The three study areas are located in the zone of continuous permafrost and are dominated by polygonal tundra (Figure 1).

The first is located on Samoylov Island in the Lena River Delta (LEN; $\left.72.3676^{\circ} \mathrm{N}, 126.4838^{\circ} \mathrm{E}\right)$. The nearest weather station is located in the village of Tiksi (WMO 21824, $\sim 110 \mathrm{~km}$ southeast of the study location) and reports for the period from 2001 to 2011 give a mean annual air temperature (MAAT) of $-12.8^{\circ} \mathrm{C}$. The vegetation on Samoylov Island is described in the Circumpolar Arctic Vegetation Map (CAVM) as unit W2 (sedge, moss, dwarf-shrub, wetland; Walker et al., 2005).

The second study area is located in the Indigirka Lowlands, $30 \mathrm{~km}$ northwest of the village of Chokurdakh near the World Wildlife Fund station Kytalyk at the Berelekh River, a tributary of the Indigirka River (IND; $70.8296^{\circ} \mathrm{N}$, $\left.147.4895^{\circ} \mathrm{E}\right)$. This is the coldest of the three sites, with an MAAT of $-13.1{ }^{\circ} \mathrm{C}$ at the nearest weather station in Chokurdakh (WMO 21946Tab.1). The vegetation at this site is described in the CAVM as unit W3 (sedge, moss, low-shrub, wetland; Walker et al., 2005).

The third study area is located in the Kolyma River Delta near the village of Pokhodsk, $40 \mathrm{~km}$ northwest of the city of Chersky (KOL; $\left.69.0790^{\circ} \mathrm{N}, 160.9634^{\circ} \mathrm{E}\right)$. This site is the southernmost and warmest of all three sites, with an MAAT

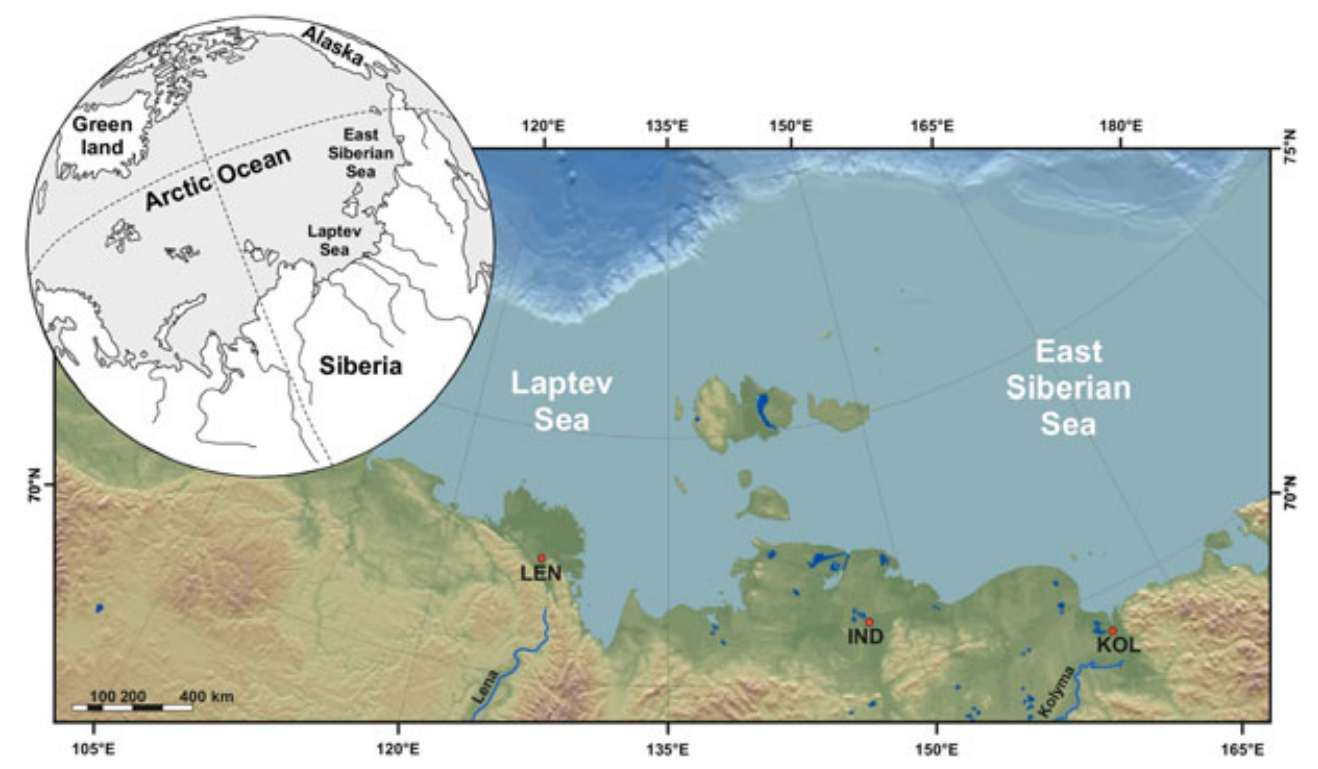

Figure 1 Position of the study sites LEN (Lena Delta), IND (Indigirka lowland), KOL (Kolyma Delta) marked by red circles. Digital elevation model compiled by G. Grosse (AWI Potsdam). [Colour figure can be viewed at wileyonlinelibrary.com] 
of $-9.7^{\circ} \mathrm{C}$ at the nearest weather station in Chersky (WMO 25123). The vegetation cover of this site is described in the CAVM as unit S2 (low shrub tundra; Walker et al., 2005). Meteorological parameters of all three sites are summarised in Table 1 and characteristic soil types and vegetation cover in Table 2. Thaw depths were determined in all study areas between mid and end of August by pushing a rod into the thawed ground down to resistance and measuring the distance between the ground surface and the frost table. Although re-freezing of the soils in all study areas started in September (as indicated by decreasing soil temperatures), the late summer thaw depths are a good approximation of the maximum annual thaw depths as the thaw rates in the second half of August and September are usually low (Kutzbach et al., 2004; Boike et al., 2013).

\section{Soil Sampling}

All soil cores were labelled by their specific study site (LEN, IND, KOL), a consecutive number and, in the polygonal tundra, either by their location on a polygon ridge $(-\mathrm{R})$ or a polygon centre $(-\mathrm{C})$. On Samoylov Island, two soil profiles each approximately $1 \mathrm{~m}$ deep from a polygon ridge (LEN-1-R) and a polygon centre (LEN-1-C) were sampled in August 2012. At the Indigirka site, one soil profile from a polygon ridge (IND-1-R) was sampled in August 2011 and described in detail by Teltewskoi et al. (2016). Eight pairs of soil cores were drilled ( $0.5 \mathrm{~m}$ apart) in the Kolyma

Table 1 Climatological parameters of the three study sites. Mean annual air temperature (MAAT) and mean temperatures in January and July from a period between 2001 and 2011 as well as mean annual precipitation (MAP, from the period between 2001 and 2003; Russia's Weather Server, 2013).

Site Maat $\left({ }^{\circ} \mathrm{C}\right)$ Temp. January $\left({ }^{\circ} \mathrm{C}\right)$ Temp. July $\left({ }^{\circ} \mathrm{C}\right)$ MAP $(\mathrm{mm})$

\begin{tabular}{lrlll}
\hline LEN & -12.8 & -29.8 & 9.1 & 315 \\
IND & -13.1 & -33.8 & 11.8 & 221 \\
KOL & -9.8 & -32.4 & 14 & 202 \\
\hline
\end{tabular}

River Delta near Pokhodsk (Schirrmeister et al., 2016). In three ice-wedge polygons, a soil core was drilled on the polygon ridge (KOL-1-R, KOL-3-R, KOL-4-R) and in the polygon centre (KOL-1-C, KOL-3-C, KOL-4-C). Additionally, two soil cores were drilled on the floodplain of the Kolyma River (KOL-5, KOL-7). Drilling followed the method described by Zubrzycki (2011). A comprehensive overview on the different soil profiles is given in Supporting Information Figure S1.

\section{Soil Chemistry}

The samples from the Indigirka Lowlands and the Kolyma River Delta were analysed for water content, bulk density and ammonium and nitrate contents in the field laboratory, directly after drilling. Total carbon (TC) and total N (TN) contents were analysed after transport in frozen state to the laboratories at the University of Hamburg, as were all the soil chemistry measurements on samples from the Lena River Delta. The water content of the samples was calculated by the mass loss of the samples after drying at $105^{\circ} \mathrm{C}$. Bulk density was calculated using the dry mass of the samples and the volume of a cylindrical subsample. Extractable ammonium $\left(\mathrm{NH}_{4}^{+}\right)$and nitrate $\left(\mathrm{NO}_{3}^{-}\right)$were measured photometrically after extraction with $0.0125 \mathrm{M} \mathrm{CaCl}_{2}$ (VDLUFA, 1991). In the field laboratory in the Kolyma River Delta and the Indigirka Lowlands, these extracts were measured by using photometrical test-kits for ammonium and nitrate analyses (LCK304, 0.015-2.0 mg L $\mathrm{m}^{-1}$ and LCK339, 0.23-13.5 mg L ${ }^{-1}$; HACH-Lange GmbH, Germany). TC and TN contents in the soil samples were measured using a $\mathrm{C} / \mathrm{N}$ analyser (Variomax CNMS, Elementar Analysensysteme GmbH, Germany). All values were multiplied by the bulk density of the sample and expressed as element contents (in $\mathrm{g} \mathrm{N} \mathrm{m}^{-3}$ or $\mathrm{g} \mathrm{C} \mathrm{m}^{-3}$ ). Potential annual liberation of $\mathrm{N}$ was calculated (in mg $\mathrm{N}$ $\mathrm{m}^{-2}$ year ${ }^{-1}$ ) by multiplying the mean annual increase in ALT (as modelled by CryoGrid2) by the mean $\mathrm{N}$ content in the permafrost.

Table 2 Overview of the different soil cores, soil types, dominant species at the drilling site and thaw depths.

\begin{tabular}{lllll}
\hline Core number & \multicolumn{1}{c}{ Site } & \multicolumn{1}{c}{ Soil type } & \multicolumn{1}{c}{ Vegetation } & Thaw depth $(\mathrm{cm})$ \\
\hline IND-1-R & Polygon ridge & Typic Historthel & Betula nana/Ledum palustre & $42^{\mathrm{a}}$ \\
KOL-1-R & Polygon ridge & Typic Aquiturbel & B. nanalAlnus glutinosa & $47^{\mathrm{b}}$ \\
KOL-1-C & Polygon centre & Typic Fibristel & Pond & $61^{\mathrm{b}}$ \\
KOL-3-R & Polygon ridge & Glacic Histoturbel & Carex aquatilis/Eriophorus angustifolium & $46^{\mathrm{b}}$ \\
KOL-3-C & Polygon centre & Fluvaquentic Sapristel & C. aquatilis/E. angustifolium & $53^{\mathrm{b}}$ \\
KOL-4-R & Polygon ridge & Fluvaquentic Historthel & B. nanalA. glutinosa & $35^{\mathrm{b}}$ \\
KOL-4-C & Polygon centre & Fluvaquentic Sapristel & C. aquatilis/E. angustifolium & $53^{\mathrm{b}}$ \\
KOL-5 & Floodplain & Fluvaquentic Aquorthel & C. aquatilis/E. angustifolium & $59^{\mathrm{b}}$ \\
KOL-7 & Floodplain & Fluvaquentic Aquorthel & Equisetum fluviatile & $61^{\mathrm{b}}$ \\
LEN-1-R & Polygon ridge & Typic Aquiturbel & B. nanalL. palustre & $30^{\mathrm{b}}$ \\
LEN-1-C & Polygon centre & Typic Historthel & C.aquatilis/E. angustifolium & $41^{\mathrm{b}}$
\end{tabular}

Thaw depths were measured at ${ }^{a}$ the end of August 2011 and ${ }^{b}$ the end of August 2012. Specification of the soil types were conducted following US Soil Taxonomy (Soil Survey Staff, 2010). 


\section{Cryolithology}

Sediment and ice structures were described, sketched and photographed in the field to document the stratigraphy of the soil profiles. The different sediment layers of the soils were characterised using the grain-size distribution, colour, content and type of plant remains as well as the amount and structures of segregation ice (French and Shur, 2010). Grain-size distribution was analysed using an LS 200 laser particle analyser (Beckman-Coulter) and computed with GRADISTAT 4.0 (Blott and Pye, 2001). Volumetric contents of ice, mineral soil and organic matter were calculated following Strauss et al. (2012, 2013), using absolute ice contents, total carbon contents and bulk density estimation.

\section{Monitoring of Active-Layer Thermal Dynamics}

To assess current on-site soil-climatic conditions, annual monitoring of soil moisture and temperature was conducted at all three study areas in a soil profile on a polygon ridge. At the Kolyma site, this monitoring included the active layer and the permafrost, whereas the monitoring at the two other sites was conducted only in the active layer. The longest available record of ground temperatures and ALT for Samoylov Island between 1998 and 2011 is given by Boike et al. (2013). Comparable data for the Kytalyk study site between 2008 and 2009 are summarised by Parmentier et al. (2011) and between 2009 and 2011 by Iwahana et al. (2014).

The hourly climate data record (air temperature, net radiation, humidity, wind speed and direction, rainfall, snow depth) on Samoylov Island were derived from a weather station installed in 1998 (Boike et al., 2008). Continuous monitoring of soil temperature and soil moisture was initiated in 1998. Soil temperature was recorded using calibrated thermistors $\left( \pm 0.1^{\circ} \mathrm{C}\right.$, Campbell Scientific Ltd, UK), and liquid water content was calculated from time domain reflectometry measurements (Tektronix 1502 and TDR100, Campbell Scientific) using the semi-empirical mixing model of Roth et al. (1990). Ice was included as the fourth phase (air, water, soil, ice) to account for the composition of permafrost-affected soils. The precision of the instrument is $\pm 0.01 \mathrm{~m}^{3} \mathrm{~m}^{-3}$, and the absolute accuracy $\pm 0.05 \mathrm{~m}^{3} \mathrm{~m}^{-3}$.

Monitoring at the Indigirka site took place between July 2011 and July 2012 for temperature and in July-August 2011 for soil moisture, and at the Kolyma site between July 2012 and July 2013 for soil temperature and soil moisture. The data sets were obtained by HOBO 12-bit temperature and soil moisture smart sensors (S-TMB-M002 and SSMD-M005, Onset Computer Corporation, USA) at different depth below the surface. All data loggers measured their specific value with a temporal resolution of $30 \mathrm{~min}$. The overall accuracy of the temperature measurements by the S-TMBM002 sensors is $\pm 0.5^{\circ} \mathrm{C}$, and the overall accuracy of the soil moisture sensors (S-SMD-M005) is $\pm 0.05 \mathrm{~m}^{3} \mathrm{~m}^{-3}$. Soil moisture values obtained below the operating temperature of $0 \pm 0.5^{\circ} \mathrm{C}$, after freezing of the active layer, are not considered.

\section{Modelling ALT}

The evolution of the ALT was simulated at each site under different climate warming scenarios using the CryoGrid2 permafrost model (Westermann et al., 2012; Langer et al., 2013). CryoGrid 2 is a one-dimensional transient permafrost model, which calculates ground temperature according to conductive heat transfer with phase change in the soil and in the snow pack. The model is forced by time series of surface temperature and snow depth at the upper boundary of the model domain and with a geothermal heat flux at the lower boundary. The modelled ground domain extends to a depth of $600 \mathrm{~m}$. The thermal properties of the ground domain were set according to the specific ground composition at each site, consisting of the volumetric contents of organic matter, mineral soil, ice and water. For the uppermost $2 \mathrm{~m}$, this information was directly inferred from cryolithological analyses of the soils, whereas the composition of the deeper ground was estimated according to field observations and geological maps (Table S1). The model assumes a static soil water content, so that moisture changes due to precipitation, snow melt or the general ground water level are neglected. However, estimates of future changes in landscape wetness would be speculative. The thermal properties of the snow cover were calculated according to snow density, which was estimated using a scheme similar to the snow cover reanalysis product by the Canadian Meteorological Centre (CMC, Brasnett, 1999). Complex thermomechanical permafrost degradation processes such as surface subsidence, thermokarst and erosion were explicitly excluded from the modelling as reliable parameterisations do not yet exist.

The model was forced by air temperature, which is a good approximation of the surface temperature on timescales longer than the diurnal cycle. For model spin-up and validation, the model was run from 1979 to 2013. A forcing dataset was generated for each site using ERAINTERIM reanalysis data for air temperature (Dee et al., 2011) and the CMC snow reanalysis product for snow depth. The forcing dataset was found to be realistic in comparison with site meteorological data (cf. Langer et al., 2013). The model was initialised assuming thermal equilibrium based on the average air temperature from 1979 to 1989. After initialisation, the model was brought into a dynamic equilibrium by running the model for 50 years using the same period. The following period from 1989 to 2012 was used to assess the accuracy of the modelled annual active-layer dynamics. A reasonable agreement with differences of $<5 \mathrm{~cm}$ between modelled and observed maximum ALT was found at each site. For simulating ALT from 2012 to 2100 , we generated a fully synthetic forcing dataset for each site. Increasing air temperature trends for each site were extracted from climate projections based on the CCSM4 coupled climate model (Meehl et al., 2012). Specifically, we made use of the Permafrost Carbon 
RCN forcing dataset obtained from Earth System Grid (2015). The same product was used by Koven et al. (2015) for investigating permafrost $\mathrm{C}$ feedback processes. We selected a moderate and a strong climate warming scenario following the Representative Concentration Pathways (RCP) 4.5 and 8.5. At the investigated sites, RCP4.5 corresponds to a warming trend of approximately $0.01^{\circ} \mathrm{C}$ year ${ }^{-1}$ and RCP8.5 to one of about $0.06^{\circ} \mathrm{C} \mathrm{year}^{-1}$. The temperature trends of the RCP scenarios were added to a synthetic air temperature time series, made up of randomly selected years during the period from 1979 to 2012. The corresponding snow depth forcing was modified to avoid snow above $0^{\circ} \mathrm{C}$. In addition, the model was forced with a synthetic air temperature time series without trend as a control run.

\section{Statistics and Data Presentation}

Volumetric mean contents of $\mathrm{C}, \mathrm{N}$, ammonium, nitrate and water and mean values for the bulk density in the active layer and permafrost were calculated for each of the 11 records. The eight soil profiles from the Kolyma site were allocated to three groups (polygon ridges, polygon centres, floodplain), and mean elemental contents were calculated for the three groups. Differences between the active layer and permafrost were investigated using a Student's twosample $t$-test by aggregating the data and using the replicate cores for a single test per site. One-way ANOVA was applied for each of the investigated soil parameters and separately for the active layer and permafrost with the different sites (polygon ridges, polygon centres, floodplain) as independent variables to identify differences between the three sites. For each soil profile, Pearson's correlation coefficient was calculated between the $\mathrm{TC}$ and $\mathrm{TN}$ contents on the one side and the contents of ammonium on the other side. Mean annual liberation of $\mathrm{N}$ was estimated by multiplying the mean densities of ammonium-N with the modelled annual ALT increase for the three groups from the Kolyma site and also for the three soil profiles from Samoylov Island and the Indigirka site.

\section{RESULTS}

\section{Cryolithology}

The soil profiles at Samoylov Island were characterised by relatively high volumetric contents of mineral components $\left(0.2-0.6 \mathrm{~m}^{3} \mathrm{~m}^{-3}\right)$ and low volumetric ice contents $(0.3-$ $0.6 \mathrm{~m}^{3} \mathrm{~m}^{-3}$ ) compared to the other sites. The profile of the polygon ridge (LEN-1-R) consisted of alternations between mineral and organic material, while the profile of the polygon centre (LEN-1-C) was mainly composed of organic material. Thaw depth at the end of August 2012 was $30 \mathrm{~cm}$ on the polygon ridge and $40 \mathrm{~cm}$ in the polygon centre. The dominant texture in both soil profiles was sandy silt. The profile IND-1-R consisted of peat with many inclusions of silt between 15 and $30 \mathrm{~cm}$ depth. Volumetric contents of organic material were between 0.1 and $0.5 \mathrm{~m}^{3} \mathrm{~m}^{-3}$ and volumetric ice contents between 0.2 and $0.9 \mathrm{~m}^{3} \mathrm{~m}^{-3}$. Thaw depth in August 2011 was $42 \mathrm{~cm}$. There was no visible cryostructure in the frozen part of this profile. The dominant texture of the mineral components in this profile was sandy silt.

The cores from the Kolyma River Delta were dominated by high volumetric contents of water and ice (cf. Figure S1; Table S1). Thaw depth at the end of August 2012 was highest on the floodplain $(60 \pm 1 \mathrm{~cm})$ and in the polygon centres $(56 \pm 4 \mathrm{~cm})$, and lowest on the polygon ridges $(43 \pm 5 \mathrm{~cm})$. In the frozen parts, the cryostructure was horizontal reticulate, with several horizontal ice belts and lenses $(5-10 \mathrm{~mm}$ thick) and thin $(\leq 1 \mathrm{~mm})$ vertical ice veins. The cores from the ridges contained several horizons with volumetric contents of mineral components of about $0.5 \mathrm{~m}^{3} \mathrm{~m}^{-3}$. The floodplain cores contained approximately $0.3 \mathrm{~m}^{3} \mathrm{~m}^{-3}$ mineral components. The volumetric content of organic matter in the floodplain cores was lower than that on the polygon ridges and in the polygon centres, with contents between 0.03 and $0.06 \mathrm{~m}^{3} \mathrm{~m}^{-3}$. The mineral soil material was composed of clay, silt and fine-grained sand. The dominant texture on the polygon ridges and polygon centres was sandy silt, whereas that on the floodplain was silty clay.

\section{Soil Chemistry}

Overall, the TC contents varied from less than 20 to almost $100 \mathrm{~kg} \mathrm{~m}^{-3}$ within and between the different soil profiles (Figure 2). The TC and TN contents were highly variable, dependent on the soil stratigraphy (cf. Figures S1 and S3). The stratigraphy from the polygon centres in Pokhodsk was rather homogeneous, similar to the TC contents in these soils (Table 3 ). The TN contents were less diverse than the TC contents. All soil profiles from the Kolyma study area showed volumetric TN contents between 2 and $4 \mathrm{~kg} \mathrm{~m}^{-3}$. The Lena soils appeared to contain the lowest TN contents, with mean values around $1 \mathrm{~kg} \mathrm{~m}^{-3}$. The highest TN contents were found in the Indigirka soil profile (IND-1-R), showing values up to $6 \mathrm{~kg} \mathrm{~m}^{-3}$ (cf. Figure S3). A significant increase in the TC and TN contents in permafrost was found only in the soil profile LEN-1-R.

Ammonium contents (in $\mathrm{mg} \mathrm{N} \mathrm{m}^{-3}$ ) were significantly higher in the permafrost than in the active layer, irrespective of the study area, study site and soil stratigraphy (Figure 2). The highest ammonium contents in the permafrost were found in the soil cores from the Kolyma floodplain, significantly higher than those in the permafrost of the polygon ridges and polygon centres there. The smallest amounts of ammonium in permafrost were observed in the soil cores from the Lena Delta (Table 3), whereas the highest amounts in the active layer were found in the three soil cores of the polygon centres in the Kolyma Delta. In contrast, the volumetric contents of nitrate were about ten times lower than the contents of ammonium and showed no overall increases towards the permafrost (Table 3). A comprehensive 

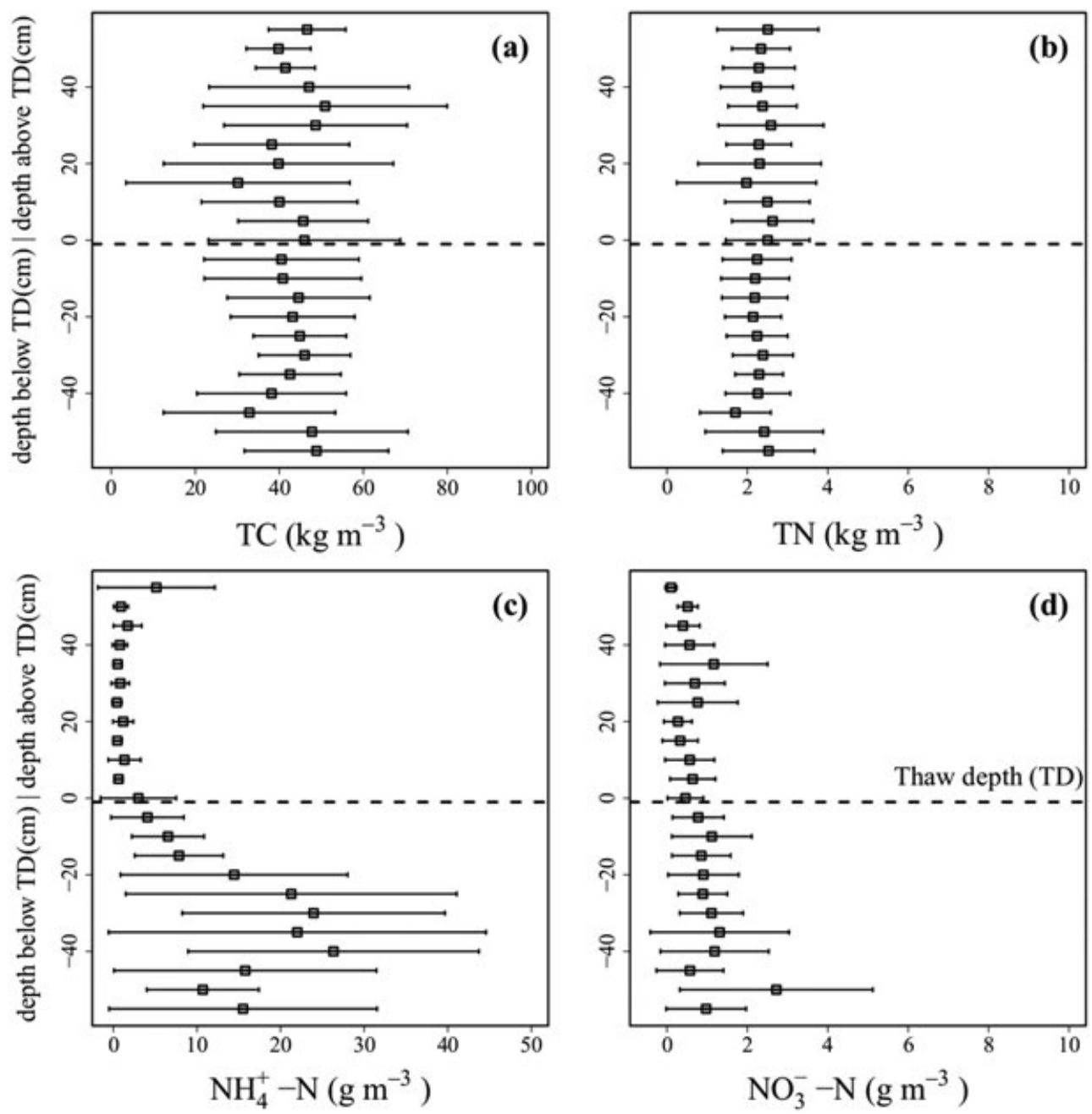

Figure 2 Contents of total carbon (a) and total nitrogen (b), ammonium (c) and nitrate (d) in soil cores from eastern Siberia. Mean elemental contents (grey boxes) and standard deviations (black lines) of all investigated soil cores are shown. Depth distribution of the elemental contents is adjusted to the respective thawing depth (TD) as a measure of the current ALT of each soil profile.

overview of the soil chemistry of all soil profiles from the three study areas is given in Figure S3.

Overall, there was no correlation between the ammonium and TC or TN contents in all soil profiles $\left(R_{\mathrm{TC}}=0.01 ; R_{\mathrm{TN}}=0.01\right)$. Only in soil profile LEN-1-C was there a strong positive relationship between ammonium and TC $(R=0.86)$, whereas soil profile KOL-7 showed a moderate negative relationship between them $(R=-0.55)$. No significant differences in the TN and nitrate contents were found between the active layer and the permafrost in the polygon tundra and the floodplain of the Kolyma Delta. The TC contents significantly increased only in the permafrost of the polygon centres in the Kolyma Delta. By contrast, significant differences between the ammonium contents in the active layer and the permafrost were observed in all investigated soil units: the ammonium contents in the permafrost were between two-fold (polygonal tundra, Lena Delta) and 40-fold (floodplain, Kolyma Delta) higher than the those in the active layer (Table 1).

\section{Soil Thermal Dynamics}

The soil temperature and volumetric water content profiles at the three sites show the typical active-layer processes in permafrost-affected soils. The soil profiles are characterised by: (i) large seasonal temperature amplitudes (approximately -25 to $+10^{\circ} \mathrm{C}$ ) in the uppermost layers; (ii) seasonal freeze-thaw, as indicated by the decrease/increase of liquid water content; (iii) pronounced temperature stabilisation during phase change at $0^{\circ} \mathrm{C}$ during freezeback ('zero curtain') and spring; and (iv) liquid water contents up to $\sim 0.1 \mathrm{~m}^{3} \mathrm{~m}^{-3}$ in frozen soils. The volumetric water contents of the polygon ridges ranged between 0.1 and $0.6 \mathrm{~m}^{3} \mathrm{~m}^{-3}$, whereas the centre of the polygon was always saturated (water contents up to $1 \mathrm{~m}^{3} \mathrm{~m}^{-3}$ ). Differences in the water 
Table 3 Average contents of inorganic $\mathrm{N}$ compounds, total $\mathrm{C}$ and total $\mathrm{N}$ in the active layer (AL) and the permafrost (PF). Mean values of single soil profiles are presented for the study areas in the Lena Delta (LEN) and the Indigirka lowlands (IND). Mean values and standard deviations of three and two soil profiles, respectively, are presented for the study area in the Kolyma Delta (KOL). Due to the lack of replicates in the other study areas, statistical analyses were conducted only for the Kolyma study area. Differences between the polygon ridges the polygon centres and the floodplains were investigated by one-way ANOVA. Significant differences between the active layer at different sites are indicated by superscripted upper case letters, significant differences between the frozen ground of the polygon ridges, the polygon centres and the floodplains are indicated by superscripted lower case letters. Significant differences between the active layer and the permafrost are indicated by asterisks: $* p<0.05, * * p<0.01$.

\begin{tabular}{|c|c|c|c|c|c|c|c|}
\hline- & Site & $-n \mathrm{TC}\left(\mathrm{kg} \mathrm{m}^{-3}\right)$ & $\mathrm{TN}\left(\mathrm{kg} \mathrm{m}^{-3}\right)$ & $\mathrm{NH}_{4}^{+}\left(\mathrm{g} \mathrm{m}^{-3}\right)$ & $\mathrm{NO}_{3}^{-}\left(\mathrm{g} \mathrm{m}^{-3}\right)$ & Water content (vol.\%) & Bulk density $\left(\mathrm{g} \mathrm{cm}^{-3}\right)$ \\
\hline \multirow{2}{*}{ LEN } & & PF 130 & 1.3 & 5.49 & 1.27 & 57.8 & 0.3 \\
\hline & & PF 122.1 & 1.1 & 3.58 & 0.04 & 60.4 & 0.49 \\
\hline \multirow[t]{2}{*}{ IND } & Polygon ridge & AL 168.3 & 3 & 0.75 & 1.98 & 75.3 & 0.22 \\
\hline & & PF 154.7 & 2.9 & 7.81 & 2.32 & 84.8 & 0.14 \\
\hline \multirow{4}{*}{ KOL } & Polygon centre & AL $345.7 \pm 0.7$ & $2.4 \pm 0.2$ & $2.3 \pm 1.5$ & $0.8 \pm 0.5$ & $73.3 \pm 7.5^{\mathrm{B}}$ & $0.24 \pm 0.15^{\mathrm{B}}$ \\
\hline & & PF $352.6 \pm 0.2 * * \mathrm{a}$ & $2.4 \pm 0.6$ & $13.2 \pm 4.4 * \mathrm{~b}$ & $0.9 \pm 0.2$ & $80.4 \pm 5.1^{\mathrm{a}}$ & $0.30 \pm 0.02^{\mathrm{b}}$ \\
\hline & Floodplain & AL $236.6 \pm 9.8$ & $2.4 \pm 0.9$ & $0.6 \pm 0.4$ & $0.5 \pm 0.2$ & $50.8 \pm 7.0^{\mathrm{B}}$ & $0.58 \pm 0.11^{\mathrm{A}}$ \\
\hline & & PF $236.4 \pm 12.9^{b}$ & $1.9 \pm 0.5$ & $24.2 \pm 12.6^{* \mathrm{a}}$ & $1.4 \pm 0.8$ & $53.0 \pm 1.8^{\mathrm{b}}$ & $0.62 \pm 0.10^{\mathrm{a}}$ \\
\hline
\end{tabular}

content indicate differences in the texture/porosity of the soil (Sphagnum peat with high volume, very low dry weight and up to nearly $100 \%$ porosity), as well as depth of the sensor (the surface sensors showing drying and wetting in response to rain events). At all sites, snow meltwater infiltrated and warmed the (frozen) soil during spring. The main difference between the three study sites was that soil temperature in winter was substantially higher in the Kolyma Delta site than in the two other sites.

At the Lena Delta site, soil temperature was recorded in the active layer between 6 and $38 \mathrm{~cm}$ b.s. Water contents in the same soil profile were recorded between 5 and $34 \mathrm{~cm}$ b.s. The soil was continuously frozen approximately between October 2011 and May 2012. Thawing and refreezing of the soil occurred between May and June 2012. Minimum soil temperatures ranged between approximately $-27^{\circ} \mathrm{C}$ at $6 \mathrm{~cm}$ b.s. and $-24^{\circ} \mathrm{C}$ at $38 \mathrm{~cm}$ b.s. Volumetric liquid water contents of approximately $0.1 \mathrm{~m}^{3} \mathrm{~m}^{-3}$ were measured during the winter period in all soil layers. Water contents increased quickly after soil thaw. The highest volumetric water contents in the summer $\left(>0.6 \mathrm{~m}^{3} \mathrm{~m}^{-3}\right)$ were measured at $22 \mathrm{~cm}$ b.s., whereas the uppermost soil layer (5 cm b.s.) showed values between 0.3 and $0.4 \mathrm{~m}^{3} \mathrm{~m}^{-3}$ (Figure S2a).

At the Indigirka site, soil temperature was monitored at depths between 6 and $20 \mathrm{~cm}$ b.s., and water content was monitored between 12 and $30 \mathrm{~cm} \mathrm{b.S.} \mathrm{minimum} \mathrm{soil} \mathrm{tem-}$ perature in the winter period ranged between $-24^{\circ} \mathrm{C}$ at $6 \mathrm{~cm}$ b.s. and $-26^{\circ} \mathrm{C}$ at $20 \mathrm{~cm}$ b.s. Volumetric water content was measured briefly between mid-July 2011 and mid-August 2011. The highest volumetric water contents between 0.4 and $0.5 \mathrm{~m}^{3} \mathrm{~m}^{-3}$ were measured at $27 \mathrm{~cm} \mathrm{b.s.,}$ and the lowest (approximately $0.1 \mathrm{~m}^{3} \mathrm{~m}^{-3}$ ) at $12 \mathrm{~cm} \mathrm{b.s.}$ (Figure S2b).
The soil temperature data at the Kolyma Delta site include continuous records from the active layer and permafrost to $95 \mathrm{~cm}$ b.s. The highest variation was observed in the uppermost soil layers (to $13 \mathrm{~cm}$ b.s.), where minimum temperature was below $-20^{\circ} \mathrm{C}$. The temperature in the deeper soil layers varied less, with a minimum between approximately $-18^{\circ} \mathrm{C}$ at $25 \mathrm{~cm}$ b.s. and $-14^{\circ} \mathrm{C}$ at $95 \mathrm{~cm}$ b.s. Below $50 \mathrm{~cm}$ depth, soil temperature remained perennially below $0^{\circ} \mathrm{C}$, consistent with the maximum observed ALT of $43 \pm 5 \mathrm{~cm}$ for polygon ridges at this site. Soil moisture in the active layer is affected mainly by summer precipitation and soil thaw as well as by drying out during rain-free periods. The highest volumetric moisture content of $0.5 \mathrm{~m}^{3} \mathrm{~m}^{-3}$ was recorded at $14 \mathrm{~cm}$ b.s. The general pattern shows moister conditions in the middle of the active layer (14 and $23 \mathrm{~cm}$ depth), while the deepest sensor (at $28 \mathrm{~cm}$, directly above the permafrost) measured slightly lower volumetric water contents (Figure S2c).

\section{ALT Evolution}

The evolution of ALT under RCP4.5 and RCP8.5 climate warming trends was simulated for all soil profiles at the three field sites. The model predicted reasonable thaw depths under current climate conditions at all sites (Figure 3). To display ALT evolution we used a 5-year moving average filter that smoothed out high-frequency ALT changes due to individual hot and cold years. The range of high-frequency ALT changes is displayed as shaded areas, and the ranges can be considered an estimate of the ALT uncertainty resulting from the random composition of the forcing dataset. At all sites, the simulations reveal an almost stable ALT under the RCP4.5 scenario, with only minor deviations from the control runs until 2100 (Figure 3). 

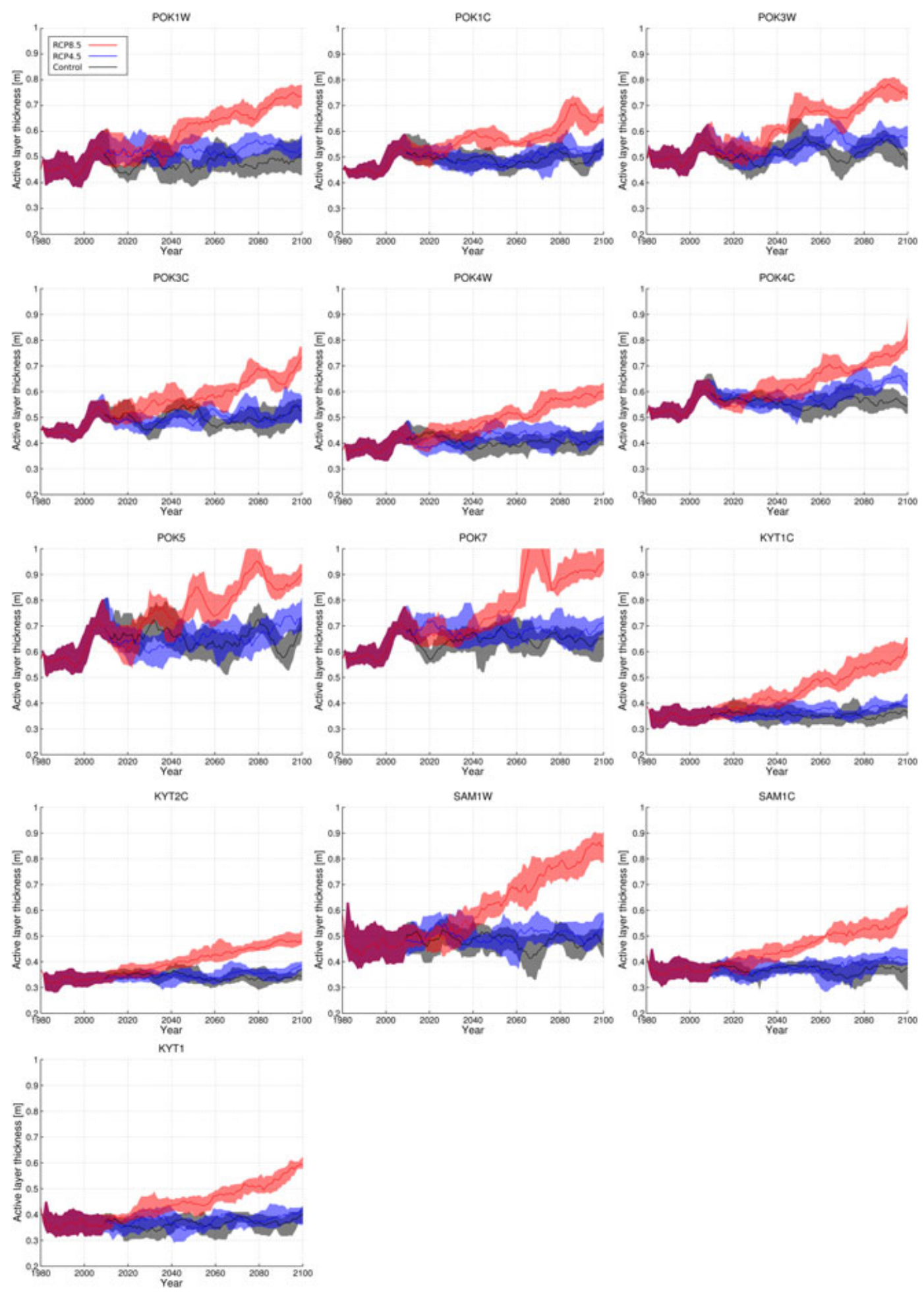

Figure 3 Modelled active-layer thickness (ALT) for all soil profiles in the Kolyma Delta (KOL), Indigirka lowlands (IND) and Lena Delta (LEN). The ALT simulations were performed for two climate warming scenarios following the representative concentration pathways RCP4.5 and RCP8.5. A control run without warming trend is shown for comparison. The shaded areas indicate the range of high-frequency ALT variations within a 5-year averaging window. [Colour figure can be viewed at wileyonlinelibrary.com] 
Table 4 Increase of active-layer thickness (ALT) in the three study areas until 2100 (RCP8.5) and annual N liberation in this period. The results from the Kolyma Delta (KOL) are based on three and two soil profiles, respectively. Significant differences are indicated by superscript lower case letters and the results of the respective ANOVA are presented. The results from the study areas in the Lena Delta (LEN) and the Indigirka lowlands (IND) are each based on one soil profile.

\begin{tabular}{|c|c|c|c|c|}
\hline- & Site & $n$ & ALT increase $(\mathrm{cm})$ & $\mathrm{N}$ liberation $\left(\mathrm{mg}\right.$ year $\left.{ }^{-1} \mathrm{~m}^{-2}\right)$ \\
\hline LEN & Polygon centre & 1 & $19 \pm 6$ & $8 \pm 3$ \\
\hline \multirow[t]{3}{*}{ KOL } & Polygon ridge & 3 & $22 \pm 3^{b}$ & $41 \pm 6^{\mathrm{b}}$ \\
\hline & Polygon centre & 3 & $22 \pm 5^{b}$ & $34 \pm 8^{b}$ \\
\hline & Floodplain & 2 & $29 \pm 5^{a}$ & $81 \pm 14^{\mathrm{a}}$ \\
\hline
\end{tabular}

In contrast, pronounced increases in ALT (between $14 \pm 3$ and $35 \pm 6 \mathrm{~cm}$ ) were observed for the RCP8.5 scenario. Overall, the highest ALT increases were observed for the polygon ridge on Samoylov $(35 \pm 6 \mathrm{~cm})$ and the floodplain soils in Pokhodsk $(29 \pm 5 \mathrm{~cm})$. By contrast, with average ALT increases between 19 and $22 \mathrm{~cm}$, the polygon ridge in Kytalyk, the polygon centre on Samoylov Island and the polygonal undra soils in Pokhodsk showed only minor differences (Table 2). A distinct increase in ALT outside of the shortterm variability of ALT was simulated to occur as early as 2040 for most of the investigated soil profiles. The results of the ALT modelling show that local differences in ALT evolution can be expected despite the same climate forcing (Figure 3).

Based on the ALT simulations and the measured N concentrations, we estimated the mean annual liberation of $\mathrm{N}$ until the year 2100 for the RCP8.5 scenario (Table 4). The highest $\mathrm{N}$ liberation rates were estimated for the soils on the Kolyma floodplain $\left(81 \pm 14 \mathrm{mg} \mathrm{N}\right.$ year $\left.^{-1} \mathrm{~m}^{-2}\right)$. The soils on the polygon ridges and in the polygon centres at the Pokhodsk site showed mean annual $\mathrm{N}$ liberation rates between 58 and $48 \mathrm{mg} \mathrm{N}$ year ${ }^{-1} \mathrm{~m}^{-2}$. The annual $\mathrm{N}$ liberation rates for the soils on Samoylov Island and in Kytalyk were substantially lower (between 8 and $22 \mathrm{mg} \mathrm{N}$ year $^{-1} \mathrm{~m}^{-2}$ ).

\section{DISCUSSION}

\section{Nitrogen Contents}

Our study reveals for the first time significant stores of ammonium frozen within Siberian permafrost soils. The 11 soil profiles from three study sites across the Siberian Arctic contain different lacustrine and fluvial sediments as well as peat and pure ice. Similar accumulations of ammonium were previously reported from permafrost-affected soils in Sweden and Greenland (Elberling et al., 2010; Keuper et al., 2012). As the diversity of soils and study sites represent a large geographical and geomorphological part of the Siberian lowland tundra, we suggest that the accumulation of ammonium in perennially frozen ground is a general feature of permafrost-affected soils in arctic tundra lowlands.

The availability of inorganic nitrogen in arctic soils varies substantially between seasons. The highest availability directly follows snowmelt (Hobbie and Chapin, 1996) and lowest coincides with the peak of the growing season in mid-July, when plant growth and competition are highest (Weintraub and Schimel, 2005b). However, the pool of inorganic nitrogen refills towards the end of the growing season, due to microbial mineralisation throughout this season (Chapin, 1996; Weintraub and Schimel, 2005b). As the soil profiles in all study areas were sampled at the end of the growing season, seasonal dynamics in nitrogen availability cannot explain the different ammonium contents in the active layer and permafrost.

Microbial organisms in arctic soils are adapted to low temperatures and are active down to $-15^{\circ} \mathrm{C}$ (Panikov, 2009; Mykytczuk et al., 2013; Jansson and Taş, 2014), although their temperature optima are above $0^{\circ} \mathrm{C}$ (Thamdrup and Fleischer, 1998; Mikan et al., 2002). Despite the overall frozen state of the soil, some unfrozen pore water persists in permafrost soils and is essential for microbial activity (Ershov, 1998; Jessen et al., 2014). On a timescale of $10^{3}-10^{4}$ years, even limited microbial activity under subzero conditions can substantially influence the geochemical composition of arctic permafrostaffected soils (Panikov, 2009). In soil cores from the Lena River Delta, high amounts of methane were found in depths to $4 \mathrm{~m}$ because of Holocene methanogenesis within frozen soil (Wagner et al., 2007). Evidence for the buildup of biodegradable dissolved organic carbon under anoxic and subzero conditions has also been found in arctic permafrost soils (Abbott et al., 2014; Ewing et al., 2015). Thus, we assume that the observed accumulation of ammonium in permafrost results from the coupled microbial mineralisation of organic carbon and nitrogen under low temperature and anoxic conditions.

The increase in the ammonium contents in the permafrost was highest in soils of the Kolyma Delta and lowest in those of the Lena Delta. These differences could result partly from differences in the soil temperatures between the three study areas. The soil profile in the Kolyma Delta showed minimum temperatures that were almost $10^{\circ} \mathrm{C}$ higher than in 
the two other study sites. At $25 \mathrm{~cm}$ b.s., the temperatures were even higher and showed less variation, indicating reduced influence of air temperature on soil temperature and a strong insulation of the soil, respectively. By contrast, soil temperatures in the Lena Delta were nearly identical between 6 and $38 \mathrm{~cm}$ b.s., indicating less pronounced winter insulation. These continuously higher soil temperatures throughout the year in the Kolyma Delta probably provided better conditions for the accumulation of ammonium than in the two other study areas. Furthermore, reduced insulation of the soil, especially in the soils in the Lena Delta, allows for deeper thawing during warm periods, mobilising previously accumulated stores of ammonium.

The mineral composition of the soils could also influence the amount of ammonium accumulation in them. The highest amounts of ammonium in the permafrost were found in the floodplain cores from the Kolyma Delta, which were characterised by a significantly lower amount of organic material and a finer soil texture than on the polygon ridges and in the polygon centres (silty clay). These finegrained soils tend to have a high pore volume, high water pressure during freezing and thus a high amount of unfrozen pore water (Eigenbrod et al., 1996). As unfrozen pore water is the main prerequisite for subzero microbial activity, the fine soil texture of fluvial origin in the soil cores of the floodplain of the Kolyma River could explain the high amounts of ammonium in the permafrost.

\section{ALT Evolution}

In general, the model simulated the ALT realistically for all soil profiles under current climate conditions with the climate forcing datasets used. This gave confidence about future projections of ALT increases. Nevertheless, the model and the forcing data are highly simplified. In particular, possible changes in soil moisture and the snow thermal properties are not taken into account. Langer et al. (2013) have demonstrated that uncertainties in soil moisture can result in uncertainties in the modelled ALT of about $\pm 15 \mathrm{~cm}$, whereas uncertainties in snow properties had only a minor impact on ALT. Therefore, all model results must be considered first-order estimates of possible ALT changes due to the assumed warming rates. Furthermore, permafrost modelling studies (including this one) usually do not consider all permafrost degradation processes, including thermokarst subsidence and thermo-erosion (van Huissteden and Dolman, 2012; Lee et al., 2014). As these processes are assumed to be highly sensitive to small changes in warming rates (Grosse et al., 2011; Westermann et al., 2016), we consider our estimated rates of permafrost degradation and nitrogen liberation to be conservative.

A significant increase in ALT for all soil profiles was observed only under the RCP8.5 scenario. This corresponds to findings of other permafrost sensitivity studies using different model approaches (Chadburn et al., 2015; Koven et al., 2015). Our results demonstrate that the future evolution of ALT depends strongly on the local soil composition (cf. Langer et al., 2013). In particular, the ALTs at the floodplain sites were highly sensitive to increased temperatures, probably related to the lower contents of ice and higher mineral contents of the soils compared with the soils from the polygonal tundra.

\section{Nitrogen Liberation}

Our ALT model predicts significant permafrost thaw under the RCP8.5 scenario: we expect a mean increase in ALT between 0.35 and $0.44 \mathrm{~cm}_{\text {year }}{ }^{-1}$. Thawing permafrost will liberate formerly frozen $\mathrm{N}$ stores. The calculated annual liberation of $\mathrm{NH}_{4}^{+}-\mathrm{N}$ across all soil cores until the year 2100 is between 8 and $81 \mathrm{mg} \mathrm{N} \mathrm{m}^{-2}$ year $^{-1}$. The highest rates of $\mathrm{N}$ liberation were calculated for the soil cores from the Kolyma floodplain, where ammonium contents in permafrost are highest and the modelled increase of ALT is greatest. A slightly greater amount of $\mathrm{N}$ release than in the present study was projected from thawing permafrost soils in Swedish peatlands (30-130 mg N m${ }^{-2}$ year $^{-1}$; Keuper et al., 2012). Our estimated annual $\mathrm{N}$ liberation from thawing permafrost reaches values up to the amount of annual $\mathrm{N}$ fixation rates in arctic surface soils (80-130 mg N $\mathrm{m}^{-2}$; Hobara et al., 2006).

Thaw-induced liberation of $\mathrm{N}$, however, represents only a small flux compared with the overall ecosystem $\mathrm{N}$ cycling. Although annual net $\mathrm{N}$ mineralisation in arctic tundra ecosystems accounts for 50-500 $\mathrm{mg} \mathrm{N} \mathrm{m}^{-2}$ year $^{-1}$ (Nadelhoffer et al., 1992; Schmidt et al., 1999; Schimel et al., 2004), gross N mineralisation is much higher, with reported daily rates between 130 and $1500 \mathrm{mg} \mathrm{N} \mathrm{m}^{-2}$ (Kaiser et al., 2005; Buckeridge et al., 2010). Plants can also take up organic $\mathrm{N}$ forms such as amino acids (Schimel and Bennett, 2004; Näsholm et al., 2009) and the gross release of amino acids from proteins far exceeds gross $\mathrm{N}$ mineralisation rates in arctic tundra soils (Wild et al., 2013). Thus, the amount of $\mathrm{N}$ liberated by permafrost thaw is unlikely to have a major impact on the overall ecosystem $\mathrm{N}$ availability. On the other hand, substantial amounts of potentially biodegradable $\mathrm{N}$ will also be released as permafrost thaws. Keuper et al. (2012) projected that the amount of annually mineralised $\mathrm{N}$ from thawing permafrost will reach between 300 and $1300 \mathrm{mg} \mathrm{N} \mathrm{m}^{-2}$ year $^{-1}$ in the tenth year after permafrost thaw. Considering the high amounts of total $\mathrm{N}$ in our samples, the amount of $\mathrm{N}$ released by mineralisation of previously frozen organic matter will strongly exceed the amount of inorganic $\mathrm{N}$ liberated upon permafrost thaw in the long term.

Independent of the total amount of liberated $\mathrm{N}$, it is also important to know if plants can access this N. As the thaw depth peaks at the end of the growing season, when competition is low (cf. Kutzbach et al., 2004), a substantial part of liberated $\mathrm{N}$ may be immobilised temporarily due to a high sink capacity for $\mathrm{N}$ of the microbial biomass (Churchland et al., 2010). On the other hand, the roots of different Graminoid species are known to grow down to the bottom of the active layer (Callaghan et al., 1991), and Larix 
species have been shown to have access to meltwater from the permafrost (Sugimoto et al., 2002). Thus, particularly deep-rooting species will benefit from the liberation of deep $\mathrm{N}$, and the thaw-induced liberation of frozen $\mathrm{N}$ can influence the plant-species composition of arctic tundra ecosystems.

Due to the high water contents and probable anaerobic conditions in the soils, the freshly liberated nitrogen can also be released as atmospheric $\mathrm{N}$ by denitrification (Repo et al., 2009; Elberling et al., 2010; Abbott et al., 2014). Furthermore, permafrost degradation can also export inorganic $\mathrm{N}$ in water (McClelland et al., 2007; Abbott et al., 2015; Tanski et al., 2017). Thus, increased temperatures can also lead to permanent removal of $\mathrm{N}$ from these soils by denitrification and hydrological export, despite increased mineralisation of organic $\mathrm{N}$ released by permafrost thaw.

\section{CONCLUSIONS}

Our study shows that permafrost thaw can liberate substantial amounts of inorganic $\mathrm{N}$, reaching values up to the order of magnitude of the annual fixation of atmospheric $\mathrm{N}$. Although the flux of liberated inorganic $\mathrm{N}$ is small compared to the overall ecosystem $\mathrm{N}$ budget, the impacts of releasing additional $\mathrm{N}$ cannot be foreseen, because thawing will affect large areas of the northern permafrost ecosystem and permafrost thaw can also lead to increased mineralisation of organic N. On the other hand, we also demonstrate that the permafrost in arctic riverine landscapes is probably less sensitive to climate change than currently expected, because temperature increases under the RCP4.5 scenario may not lead to significant changes in ALT by the year 2100 .

Follow-up studies should determine whether the accumulation of inorganic $\mathrm{N}$ is a general characteristic of arctic permafrost soils. Furthermore, analysis of the seasonal cycle of the contents of inorganic $\mathrm{N}$ in the active layer could elucidate the accumulation of ammonium in the seasonally frozen layer and thus would also help to estimate the pace of ammonium accumulation in the permafrost.

\section{ACKNOWLEDGEMENTS}

The study presented here is part of the German-Russian joint project Polygons in tundra wetlands: state and $d y$ namics under climate variability in tundra regions (Russian Foundation of Basic Research, RFBR grant No. 1104-91332-NNIO-a and German Research Foundation, DFG grant No. KU 1418/3-1 to L.K. and DFG grant No. HE 3622/16-1 to U.H.). F.B. and L.K. were supported through the Cluster of Excellence 'CliSAP' (EXC177), University of Hamburg, funded by the German Research Foundation (DFG). F.B. was also supported through a doctoral fellowship of the University of Hamburg in accordance with the Hamburg Act for the Promotion of Young Researchers and Artists (HmbNFG). M.L., J.B. and L.K. were supported through the collaborative project 'Changing Permafrost in the arctic and its Global Effects in the 21st Century - PAGE21' funded through the seventh framework programme of the European Union. J.S. was supported by a European Research Council Starting grant (PETA-CARB, No. 338335) and the Initiative and Networking Fund of the Helmholtz Association (No. ERC-0013). We thank our colleagues who helped during the expeditions in 2011 and 2012, especially Lyudmila A. Pestryakova from the North Eastern Federal University in Yakutsk as well as Vladimir E. Tumskoy from the Lomonosov State University in Moscow.

\section{SUPPORTING INFORMATION}

Additional Supporting Information may be found online in the supporting information tab for this article.

Figure S1. Cryolithological data of soil cores from the study sites.

Figure S2. Time series of soil temperatures and soil moisture in the study sites.

Figure S3. Total carbon (TC), total nitrogen (TN), ammonium and nitrate contents, and thaw depth in the soil cores. Table S1. Summary of the input data for the ALT modelling.

\section{REFERENCES}

Abbott BW, Jones JB, Godsey SE, Larouche JR, Bowden WB. 2015. Patterns and persistence of hydrologic carbon and nutrient export from collapsing upland permafrost. Biogeosciences 12: 3725-3740. https://doi. org/10.5194/bg-12-3725-2015

Abbott BW, Larouche JR, Jones JB, Bowden WB, Balser AW. 2014. Elevated dissolved organic carbon biodegradability from thawing and collapsing permafrost. Journal of Geophysical Research: Biogeosciences 119: 2049-2063. https://doi.org/10.1002/ 2014JG002678
Aerts R. 2006. The freezer defrosting: global warming and litter decomposition rates in cold biomes. Journal of Ecology 94: 713-724. https://doi.org/10.1111/j.13652745.2006.01142.x

Barnes RT, Williams MW, Parman JN, Hill K, Caine N. 2014. Thawing glacial and permafrost features contribute to nitrogen export from Green Lakes Valley, Colorado Front Range, USA. Biogeochemistry 117: 413-430. https://doi.org/10.1007/s10533013-9886-5

Beermann F, Teltewskoi A, Fiencke C, Pfeiffer E-M, Kutzbach L. 2015. Stoichiometric analysis of nutrient availability
$(\mathrm{N}, \mathrm{P}, \mathrm{K})$ within soils of polygonal tundra. Biogeochemistry 122: 211-227. https://doi. org/10.1007/s10533-014-0037-4

Blok D, Heijmans MMPD, Schaepman-Strub G, Kononov AV, Maximov TC, Berendse F. 2010. Shrub expansion may reduce summer permafrost thaw in Siberian tundra. Global Change Biology 16: 1296-1305. https://doi.org/10.1111/j.13652486.2009.02110.x

Blott SJ, Pye K. 2001. GRADISTAT: a grain size distribution and statistics package for the analysis of unconsolidated sediments. Earth Surface Processes and Landforms 26: 1237-1248. https://doi.org/10.1002/esp.261 
Boike J, Kattenstroth B, Abramova K, Bornemann N, Chetverova A, Fedorova I, Fröb K, Grigoriev M, Grüber M, Kutzbach L, Langer M, Minke M, Muster S, Piel K, Pfeiffer E-M, Stoof G, Westermann S, Wischnewski K, Wille C, Hubberten H-W. 2013. Baseline characteristics of climate, permafrost and land cover from a new permafrost observatory in the Lena River Delta, Siberia (1998-2011). Biogeosciences 10: 2105-2128. https://doi.org/10.5194/bg10-2105-2013

Boike J, Wille C, Abnizova A. 2008. Climatology and summer energy and water balance of polygonal tundra in the Lena River Delta, Siberia. Journal of Geophysical Research 113: 1-15. https://doi.org/10.1029/ 2007JG000540

Brasnett B. 1999. A global analysis of snow depth for numerical weather prediction. Journal of Applied Meteorology 38: 726-740. https://doi.org/10.1175/15200450(1999)038<0726:AGAOSD > 2.0. $\mathrm{CO} ; 2$

Buckeridge KM, Zufelt E, Chu H, Grogan P. 2010. Soil nitrogen cycling rates in low arctic shrub tundra are enhanced by litter feedbacks. Plant and Soil 330: 407-421. https://doi.org/10.1007/s11104-009-0214-8

Callaghan TV, Headley AD, Lee JA. 1991. Root function related to the morphology, life history and ecology of tundra plants. In Plant Root Growth, an Ecological Perspective, Atkinson AD (ed). Blackwell Scientific Publications: London; 311-340.

Chadburn SE, Burke EJ, Essery RLH, Boike J, Langer M, Heikenfeld M, Cox PM, Friedlingstein P. 2015. Impact of model developments on present and future simulations of permafrost in a global land-surface model. The Cryosphere 9: 1505-1521. https://doi.org/10.5194/tc-9-1505-2015

Chapin DM. 1996. Nitrogen mineralization, nitrification and denitrification in a high arctic lowland ecosystem, Devon Island, N.W.T., Canada. Arctic and Alpine Research 28: 85-92. https://doi.org/10.2307/ 1552089

Chapin FS, Moilanen L, Kielland K. 1993. Preferential use of organic nitrogen for growth by a non-mycorrhizal arctic sedge. Nature 361: 150-153. https://doi.org/ $10.1038 / 361150 \mathrm{a} 0$

Chu H, Grogan P. 2009. Soil microbial biomass, nutrient availability and nitrogen mineralization potential among vegetationtypes in a low arctic tundra landscape. Plant and Soil 329: 411-420. https://doi.org/ 10.1007/s11104-009-0167-y

Churchland C, Mayo-Bruinsma L, Ronson A, Grogan P. 2010. Soil microbial and plant community responses to single large carbon and nitrogen additions in low arctic tundra.
Plant and Soil 334: 409-421. https://doi. org/10.1007/s11104-010-0392-4

Dee DP, Uppala SM, Simmons AJ, Berrisford P, Poli P, Kobayashi S, Andrae U, Balmaseda MA, Balsamo G, Bauer P, Bechtold P, Beljaars ACM, van de Berg L, Bidlot J, Bormann N, Delsol C, Dragani R, Fuentes M, Geer AJ, Haimberger L, Healy SB, Hersbach H, Hólm EV, Isaksen L, Kållberg P, Köhler M, Matricardi M, McNally AP, Monge-Sanz BM, Morcrette J-J, Park B-K, Peubey C, de Rosnay P, Tavolato C, Thépaut J-N, Vitart F. 2011. The ERA-Interim reanalysis: configuration and performance of the data assimilation system. Quarterly Journal of the Royal Meteorological Society 137: 553-597. https://doi.org/10.1002/qj.828

Earth System Grid. 2015. Permafrost Carbon RCN forcing data. https://www. earthsystemgrid.org/dataset/ucar.cgd.ccsm4. permafrostRCN_protocol2_forcing.html

Eigenbrod KD, Knutsson S, Sheng D. 1996. Pore-water pressures in freezing and thawing fine-grained soils. Journal of Cold Regions Engineering 10: 77-92. https:// doi.org/10.1061/(ASCE)0887-

381X(1996)10:2(77)

Elberling B, Christiansen HH, Hansen BU. 2010. High nitrous oxide production from thawing permafrost. Nature Geoscience 3: 332-335. https://doi.org/10.1038/ngeo803

Eriksson T, Öquist MG, Nilsson MB. 2010. Production and oxidation of methane in a boreal mire after a decade of increased temperature and nitrogen and sulfur deposition. Global Change Biology 16: 2130-2144. https://doi.org/10.1111/j.13652486.2009.02097.x

Ershov ED. 1998. General Geocryology. Cambridge University Press: Cambridge.

Ewing SA, O'Donnell JA, Aiken GR, Butler $\mathrm{K}$, Butman D, Windham-Myers L, Kanevskiy MZ. 2015. Long-term anoxia and release of ancient, labile carbon upon thaw of Pleistocene permafrost. Geophysical Research Letters 42: 10,730-10,738. https:// doi.org/10.1002/2015GL066296

Foley JA. 2005. Tipping points in the tundra. Science 310: 627-628. https://doi.org/ 10.1126/science. 1120104

French H, Shur Y. 2010. The principles of cryostratigraphy. Earth-Science Reviews 101: 190-206. https://doi.org/10.1016/j. earscirev.2010.04.002

Grosse G, Romanovsky VE, Jorgenson T, Anthony KW, Brown J, Overduin PP. 2011. Vulnerability and feedbacks of permafrost to climate change. Eos, Transactions American Geophysical Union 92: 73-80. https:// doi.org/10.1029/2011EO090001

Harden JW, Koven CD, Ping CL, Hugelius G, David McGuire A, Camill P, Jorgenson T,
Kuhry P, Michaelson GJ, O’Donnell JA, Schuur EAG, Tarnocai C, Johnson K, Grosse G. 2012. Field information links permafrost carbon to physical vulnerabilities of thawing. Geophysical Research Letters 39: 1-6. https://doi.org/10.1029/ 2012GL051958

Harms TK, Abbott BW, Jones JB. 2014. Thermoerosion gullies increase nitrogen available for hydrologic export. Biogeochemistry 117: 299-311. https://doi.org/ 10.1007/s10533-013-9862-0

Hobara S, Mccalley C, Koba K, Giblin AE, Weiss MS, Gettel GM, Shaver GR. 2006. Nitrogen fixation in surface soils and vegetation in an arctic tundra watershed: a key source of atmospheric nitrogen. Arctic, Antarctic, and Alpine Research 38: 363-372. https://doi.org/10.1657/15230430(2006)38[363:NFISSA]2.0.CO;2

Hobbie SE, Chapin FS. 1996. Winter regulation of tundra litter carbon and nitrogen dynamics. Biogeochemistry 35: 327-338. https://doi.org/10.1007/BF02179958

Iwahana G, Takano S, Petrov RE, Tei S, Shingubara R, Maximov TC, Fedorov AN, Desyatkin AR, Nikolaev AN, Desyatkin RV, Sugimoto A. 2014. Geocryological characteristics of the upper permafrost in atundra-forest transition of the Indigirka River Valley, Russia. Polar Science 8: 96-113. https://doi.org/10.1016/ j.polar.2014.01.005

Jansson JK, Taş N. 2014. The microbial ecology of permafrost. Nature Reviews. Microbiology 12: 414-425. https://doi.org/ 10.1038/nrmicro3262

Jessen S, Holmslykke HD, Rasmussen K, Richardt N, Holm PE. 2014. Hydrology and pore water chemistry in a permafrost weland, Ilulissat, Greenland. Water Resources Research 50: 1-16. https://doi.org/ 10.1002/2013WR014376.Received

Kaiser C, Meyer H, Biasi C, Rusalimova O, Barsukov P, Richter A. 2005. Storage and mineralization of carbon and nitrogen in soils of a frost-boil tundra ecosystem in Siberia. Applied Soil Ecology 29: 173-183. https://doi. org/10.1016/j.apsoil.2004.10.005

Keuper F, Bodegom PM, Dorrepaal E, Weedon JT, Hal J, Logtestijn RSP, Aerts R. 2012. A frozen feast: thawing permafrost increases plant-available nitrogen in subarctic peatlands. Global Change Biology 18: 1998-2007. https://doi.org/10.1111/j.13652486.2012.02663.x

Koven CD, Lawrence DM, Riley WJ. 2015. Permafrost carbon-climate feedback is sensitive to deep soil carbon decomposability but not deep soil nitrogen dynamics. Proceedings of the National Academy of Sciences USA 112: 3752-3757. https://doi. org/10.1073/pnas.1415123112 
Kutzbach L, Stoof G, Schneider W, Wille C, Abramova EN. 2004. Seasonal progression of active-layer thickness dependent on microrelief. In Reports on Polar and Marine Research - Russian-German Cooperation SYSTEM Laptev Sea: the Expedition Lena-Anabar 2003, Schirrmeister L (ed). Alfred Wegener Institute for Polar and Marine Research: Bremerhaven.

Langer M, Westermann S, Heikenfeld M, Dorn W, Boike J. 2013. Satellite-based modeling of permafrost temperatures in a tundra lowland landscape. Remote Sensing of Environment 135: 12-24. https://doi.org/ 10.1016/j.rse.2013.03.011

Lee H, Swenson SC, Slater AG, Lawrence DM. 2014. Effects of excess ground ice on projections of permafrost in a warming climate. Environmental Research Letters 9: 124006. https://doi.org/10.1088/17489326/9/12/124006

Limpens J, Heijmans MMPD, Berendse F. 2006. The nitrogen cycle in boreal peatlands. In Boreal Peatland Ecosystems, Wieder RK, Vitt DH (eds). Springer Verlag: Berlin; 195-230.

Loisel J, Yu Z, Beilman DW, Camill P, Alm J, Amesbury MJ, Anderson D, Andersson S, Bochicchio C, Barber K, Belyea LR, Bunbury J, Chambers FM, Charman DJ, De Vleeschouwer F, Fiałkiewicz-Kozieł B, Finkelstein SA, Gałka M, Garneau M, Hammarlund D, Hinchcliffe W, Holmquist J, Hughes P, Jones MC, Klein ES, Kokfelt U, Korhola A, Kuhry P, Lamarre A, Lamentowicz M, Large D, Lavoie M, MacDonald G, Magnan G, Mäkilä M, Mallon G, Mathijssen P, Mauquoy D, McCarroll J, Moore TR, Nichols J, O'Reilly B, Oksanen P, Packalen M, Peteet D, Richard PJ, Robinson S, Ronkainen T, Rundgren M, Sannel A, Tarnocai C, Thom T, Tuittila E-S, Turetsky M, Valiranta M, van der Linden M, van Geel B, van Bellen S, Vitt D, Zhao Y, Zhou W. 2014. A database and synthesis of northern peatland soil properties and Holocene carbon and nitrogen accumulation. The Holocene 24: 1028-1042. https://doi. org/10.1177/0959683614538073

Loranty MM, Goetz SJ, Beck PSA. 2011. Tundra vegetation effects on pan-Arctic albedo. Environmental Research Letters 6: 24014. https://doi.org/10.1088/1748-9326/ $6 / 2 / 024014$

MacDonald NW, Zak DR, Pregitzer KS. 1995. Temperature effects on kinetics of microbial respiration and net nitrogen and sulfur mineralization. Soil Science Society of America Journal 59: 233-240. https://doi. org/10.2136/sssaj1995.0361599500590001 0036x

McClelland JW, Stieglitz M, Pan F, Holmes RM, Peterson BJ. 2007. Recent changes in nitrate and dissolved organic carbon export from the upper Kuparuk River, North Slope, Alaska. Journal of Geophysical Research: Biogeosciences 112: G04S60. https://doi.org/10.1029/ 2006JG000371

Meehl GA, Washington WM, Arblaster JM, $\mathrm{Hu}$ A, Teng H, Tebaldi C, Sanderson BN, Lamarque JF, Conley A, Strand WG, White JB. 2012. Climate system response to external forcings and climate change projections in CCSM4. Journal of Climate 25: 3661-3683. https://doi.org/10.1175/JCLID-11-00240.1

Mikan CJ, Schimel JP, Doyle AP. 2002. Temperature controls of microbial respiration in arctic tundra soils above and below freezing. Soil Biology and Biochemistry 34: 1785-1795. https://doi.org/10.1016/S00380717(02)00168-2

Mykytczuk NCS, Foote SJ, Omelon CR, Southam G, Greer CW, Whyte LG. 2013. Bacterial growth at $-15{ }^{\circ} \mathrm{C}$; molecular insights from the permafrost bacterium Planococcus halocryophilus Or1. ISME Journal 7: 1211-1226. https://doi.org/ 10.1038/ismej.2013.8

Nadelhoffer KJ, Giblin AE, Shaver GR, Linkins AE. 1992. Microbial processes and plant nutrient availability in Arctic soils. In Arctic Ecosystems in a Changing Climate, Chapin FS, Jefferies R, Reyonolds JF, Shaver GR, Svoboda J (eds). Academic Press: San Diego; 281-300.

Näsholm T, Kielland K, Ganeteg U. 2009. Uptake of organic nitrogen by plants. New Phytologist 182: 31-48. https://doi.org/ 10.1111/j.1469-8137.2008.02751.x

Natali SM, Schuur EAG, Rubin RL. 2012. Increased plant productivity in Alaskan tundra as a result of experimental warming of soil and permafrost. Journal of Ecology 100: 488-498. https://doi.org/10.1111/j.13652745.2011.01925.x

Panikov SP. 2009. Microbial activity in frozen soils. In Permafrost Soils - Soil Biology Vol. 16, Margesin (ed). Springer: Berlin; 119-147.

Parmentier FJW, van Huissteden J, van der Molen MK, Schaepman-Strub G, Karsanaev SA, Maximov TC, Dolman AJ. 2011. Spatial and temporal dynamics in eddy covariance observations of methane fluxes at a tundra site in northeastern Siberia. Journal of Geophysical Research 116: G03016. https://doi.org/10.1029/2010JG 001637

Repo ME, Susiluoto S, Lind SE, Jokinen S, Elsakov V, Biasi C, Virtanen T, Martikainen PJ. 2009. Large $\mathrm{N}_{2} \mathrm{O}$ emissions from cryoturbated peat soil in tundra. $\mathrm{Na}$ ture Geoscience 2: 189-192. https://doi. org/10.1038/ngeo434
Rodionov A, Flessa H, Grabe M, Kazansky OA, Shibistova O, Guggenberger G. 2007. Organic carbon and total nitrogen variability in permafrost-affected soils in a forest tundra ecotone. European Journal of Soil Science 58: 1260-1272. https://doi.org/10.1111/j.1365-

2389.2007.00919.x

Roth K, Schulin R, Fluhler H, Attinger W. 1990. Calibration of time domain reflectometry for water content measurement using a composite dieletric approach. Water Resources Research 26: 2267-2273.

Russia's Weather Server. 2013. meteo. infospace.ru. Accessed 2 Februrary 2014.

Rustad LE, Campbell JL, Marion GM, Norby RJ, Mitchell MJ, Hartley AE, Cornelissen JHC, Gurevitch J. 2001. A meta-analysis of the response of soil respiration, net nitrogen mineralization, and aboveground plant growth to experimental ecosystem warming. Oecologia 126: 543-562. https:// doi.org/10.1007/s004420000544

Schaeffer SM, Sharp E, Schimel JP, Welker JM. 2013. Soil-plant N processes in a High Arctic ecosystem, NW Greenland are altered by long-term experimental warming and higher rainfall. Global Change Biology 19: 3529-3539. https://doi.org/10.1111/ gcb. 12318

Schimel JP, Bennett J. 2004. Nitrogen mineralization: challenges of a changing paradigm. Ecology 85: 591-602. https://doi.org/ 10.1890/03-8002

Schimel JP, Bilbrough C, Welker JM. 2004. Increased snow depth affects microbial activity and nitrogen mineralization in two Arctic tundra communities. Soil Biology and Biochemistry 36: 217-227. https://doi. org/10.1016/j.soilbio.2003.09.008

Schirrmeister L, Pestryakova LA, Schneider A, Wetterich S. 2016. Studies of Polygons in Siberia and Svalbard - the expeditions Kytalyk - Pokhodsk 2012, Pokhodsk 2013 and Adventdalen 2013. In Berichte zur Polar- und Meeresforschung; Reports on Polar and Marine Research. Alfred Wegener Institute for Polar and Marine Research: Bremerhaven.

Schmidt IK, Jonasson S, Michelsen A. 1999. Mineralization and microbial immobilization of $\mathrm{N}$ and $\mathrm{P}$ in arctic soils in relation to season, temperature and nutrient amendment. Applied Soil Ecology 11: 147-160. https://doi.org/10.1016/S09291393(98)00147-4

Schuur EAG, Crummer KG, Vogel JG, Mack MC. 2007. Plant species composition and productivity following permafrost thaw and thermokarst in Alaskan tundra. Ecosystems 10: 280-292. https://doi.org/10.1007/ s10021-007-9024-0 
Shaver GR, Billings WD, Chapin FS, Giblin AE, Oechel WC, Rastetter EB. 1992. The Global Change and carbon balance of arctic ecosystems changes in global terrestrial carbon cycling. Bioscience 42: 433-441.

Sistla SA, Moore JC, Simpson RT, Gough L, Shaver GR, Schimel JP. 2013. Long-term warming restructures Arctic tundra without changing net soil carbon storage. Nature 497: 615-618. https://doi.org/10.1038/ nature 12129

Soil Survey Staff. 2010. Keys to Soil Taxonomy. 11 th edition. USDA-Natural Resources Conservation Service: Washington, D.C.

Strauss J, Schirrmeister L, Grosse G, Wetterich S, Ulrich M, Herzschuh U, Hubberten HW. 2013. The deep permafrost carbon pool of the Yedoma region in Siberia and Alaska. Geophysical Research Letters 40: 6165-6170. https://doi.org/ 10.1002/2013GL058088

Strauss J, Schirrmeister L, Wetterich S, Borchers A, Davydov SP. 2012. Grain-size properties and organic-carbon stock of Yedoma Ice Complex permafrost from the Kolyma lowland, northeastern Siberia. Global Biogeochemical Cycles 26: 1-12. https://doi.org/10.1029/2011GB004104

Sugimoto A, Yanagisawa N, Naito D, Fujita $\mathrm{N}$, Maximov TC. 2002. Importance of permafrost as a source of water for plants in east Siberian taiga. Ecological Research 17: 493-503. https://doi.org/10.1046/ j.1440-1703.2002.00506.x

Swann AL, Fung IY, Levis S, Bonan GB, Doney SC. 2010. Changes in Arctic vegetation amplify high-latitude warming through the greenhouse effect. Proceedings of the National Academy of Sciences of the United States of America 107: 1295-1300. https://doi.org/10.1073/pnas.0913846107

Tanski G, Lantuit H, Ruttor S, Knoblauch C, Radosavljevic B, Strauss J, Wolter J, Irrgang AM, Ramage J, Fritz J. 2017. Transformation of terrestrial organic matter along thermokarst-affected permafrost coasts in the Arctic. Science of the Total Environment 581: 434-447. https://doi. org/10.1016/j.scitotenv.2016.12.152

Teltewskoi A, Beermann F, Beil I, Bobrov A, De Klerk P, Lorenz S, Lüder A, Michaelis D, Joosten H. 2016. 4000 years of changing wetness in a permafrost polygon peatland (Kytalyk, NE Siberia): a comparative high resolution multi-proxy study. Permafrost and Periglacial Processes 27: 76-95. https://doi.org/10.1002/ ppp.1869

Thamdrup B, Fleischer S. 1998. Temperature dependence of oxygen respiration, nitrogen mineralization, and nitrification in Arctic sediments. Aquatic Microbial Ecology 15: 191-199. https://doi.org/10.3354/ ame 015191

van Huissteden J, Dolman AJ. 2012. Soil carbon in the Arctic and the permafrost carbon feedback. Current Opinion in Environmental Sustainability 4: 545-551. https://doi.org/10.1016/j.

cosust.2012.09.008

VDLUFA. 1991. Methodenbuch. Verband Deutscher Landwirtschaftlicher Untersu chungs- und Forschungsanstalten: Darmstadt.

Wagner D, Gattinger A, Embacher A, Pfeiffer E-M, Schloter M, Lipski A. 2007. Methanogenic activity and biomass in Holocene permafrost deposits of the Lena Delta, Siberian Arctic and its implication for the global methane budget. Global Change Biology 13: 1089-1099. https://doi.org/ 10.1111/j.1365-2486.2007.01331.x

Walker DA, Raynolds MK, Daniëls FJA, Einarsson E, Elvebakk A, Gould WA, Katenin AE, Kholod SS, Markon CJ, Melnikov ES, Moskalenko NG, Talbot SS, Yurtsev BA. 2005. The Circumpolar Arctic vegetation map. Journal of Vegetation Science 16: 267-282. https://doi.org/ 10.1111/j.1654-1103.2005.tb02365.x
Weintraub MN, Schimel JP. 2005a. Nitrogen cycling and the spread of shrubs control changes in the carbon balance of arctic tundra ecosystems. Bioscience 55: 408-415. https://doi.org/10.1641/0006-3568(2005) 055[0408:NCATSO]2.0.CO;2

Weintraub MN, Schimel JP. 2005b. The seasonal dynamics of amino acids and other nutrients in Alaskan Arctic tundra soils. Biogeochemistry 73: 359-380. https://doi. org/10.1007/s10533-004-0363-z

Westermann S, Langer M, Boike J. 2012. Systematic bias of average winter-time land surface temperatures inferred from MODIS at a site on Svalbard, Norway. Remote Sensing of Environment 118: 162-167. https://doi.org/10.1016/j.rse.2011. 10.025

Westermann S, Langer M, Boike J, Heikenfeld M, Peter M, Etzelmüller B, Krinner G. 2016. Simulating the thermal regime and thaw processes of ice-rich permafrost ground with the land-surface model CryoGrid 3. Geoscientific Model Development 9: 523-546. https://doi.org/10.5194/ gmd-9-523-2016

Wild B, Schnecker J, Bárta J, Capek P, Guggenberger G, Hofhansl F, Kaiser C, Lashchinsky N, Mikutta R, Mooshammer M, Santrůčková H, Shibistova O, Urich T, Zimov SA, Richter A. 2013. Nitrogen dynamics in turbic cryosols from Siberia and Greenland. Soil Biology and Biochemistry 67: $\quad 85-93$. https://doi.org/10.1016/j. soilbio.2013.08.004

Zubrzycki S. 2011. Drilling frozen soils in Siberia. Polarforschung 81: 150-152.

Zubrzycki S, Kutzbach L, Grosse G, Desyatkin A, Pfeiffer E-M. 2013. Organic carbon and total nitrogen stocks in soils of the Lena River Delta. Biogeosciences 10: 3507-3524. https://doi.org/10.5194/bg-103507-2013 